DOI: $10.15593 / 2224-9923 / 2014.12 .10$

УДК $331.45+622.692 .4$

(C) Bartlova I., Bernatik A., 2014

\title{
SAFETY OF PIPELINES IN THE CZECH REPUBLIC
}

\author{
I. Bartlova, A. Bernatik \\ Technical University of Ostrava, \\ Ostrava, Czech Republic
}

Nowadays, in the Czech Republic pipelines represent one of possible transportation means of substances from producers to a wide range of customers, including other producers. There are $8,000 \mathrm{kms}$ of operational pipeline networks in the Czech Republic, transporting hazardous substances. Pipelines accidents mostly have serious effects on human health and lives or on the environment. The overview of the present state of pipelines safety in the Czech Republic has been prepared, and the approach to this problem in the European Union has been outlined. Information on the proposal of recommended UNECE procedures for the complex solving of pipelines safety, regarding the obligations of operators and public administration, are given. It is necessary to introduce a system that deals not only with the safety of operated pipeline alone but with the safety of the whole system - pipeline and its surroundings. The pipeline management system can guarantee a high level of human health and environment protection during the construction and operation of pipeline network.

Keywords: pipelines, accidents, safety precautions, risk analysis, pipeline management systems.

\section{К ВОПРОСУ О БЕЗОПАСНОСТИ ТРУБОПРОВОДНОГО ТРАНСПОРТА В ЧЕШСКОЙ РЕСПУБЛИКЕ}

\author{
И. Бартлова, А. Бернатик \\ Остравский технический университет, \\ Острава, Чешская Республика
}

В современной Чехии трубопроводный транспорт является одним из вариантов транспортировки различных веществ самым различным категориям потребителей, включая производителей. Общая протяженность действующих трубопроводных линий, транспортирующих опасные вещества, в настоящее время составляет 8000 км. Аварии на технологических трубопроводах в большинстве случаев создают серьезную угрозу здоровью и жизни населения, а также окружающей среде. В настоящей работе предложен анализ текущего положения дел в сфере безопасности трубопроводов в Чешской Республике, а также изложена общая концепция Европейского союза в области безопасной эксплуатации трубопроводного транспорта. Дается информация о проекте рекомендаций Европейской экономической комиссии ООН (ЕЭК ООН) по введению мероприятий для комплексного решения проблем безопасности технологических трубопроводов, включая обязанности сторон - организаций, осуществляющих эксплуатацию трубопроводов, и органов управления на государственном и местном уровнях. Обосновывается необходимость создания такой системы безопасности, которая предполагала бы не только безопасную эксплуатацию самого трубопровода, но и гарантировала бы безопасность окружающей среде. Система управления трубопроводным транспортом обеспечивает высокий уровень защиты окружающей среды и здоровья населения как при монтаже, так и при эксплуатации трубопроводных сетей.

Ключевые слова: трубопроводы, аварии, меры предосторожности, анализ рисков, системы управления трубопроводом. 


\section{Introduction}

Pipelines represent one of possible transportation means of substances from producers to a wide range of customers, including other producers. Sometimes they provide the only means of transportation of large volumes of liquid and gaseous substances on long distances. They are generally recognized as the safest and most efficient means of transportation of dangerous substances, compared to other options. Crude oil, its derivatives, and natural gas belong to the most often transported hazardous substances, and pipes dedicated to their transport are called pipelines. Pipelines accidents mostly have serious effects on human health and lives (predominantly gaseous substances), or on the environment (predominantly liquids). Economic losses by property damage, or those caused by the loss of goodwill, lost profit or paid compensations cannot be considered negligible.

Figure 1 illustrates an example of gas pipeline explosion. 24 people were killed and 132 injured after the explosion of Fluxys gas pipeline in the Ghislenghien industrial region by the town of Ath. The pipeline served for the transport of natural gas from Zeebrugge harbor on Belgian coast to France. The likely cause of this accident was the damage of pipes caused by construction machines several weeks prior to the accident. The pipeline burst after the operator started to increase the pressure.

Accidents research and analyses show that most cases in the Czech Republic endangered the environment components. However, the risk of fire and/or explosion occurrence and their effects on human health cannot be neglected.

The following are the most common causes of pipeline accidents:

- pipe dislocation by third party,

- corrosion,

- construction or material failure,

- natural contingencies (especially landslides),

- operational faults $[1,2]$.

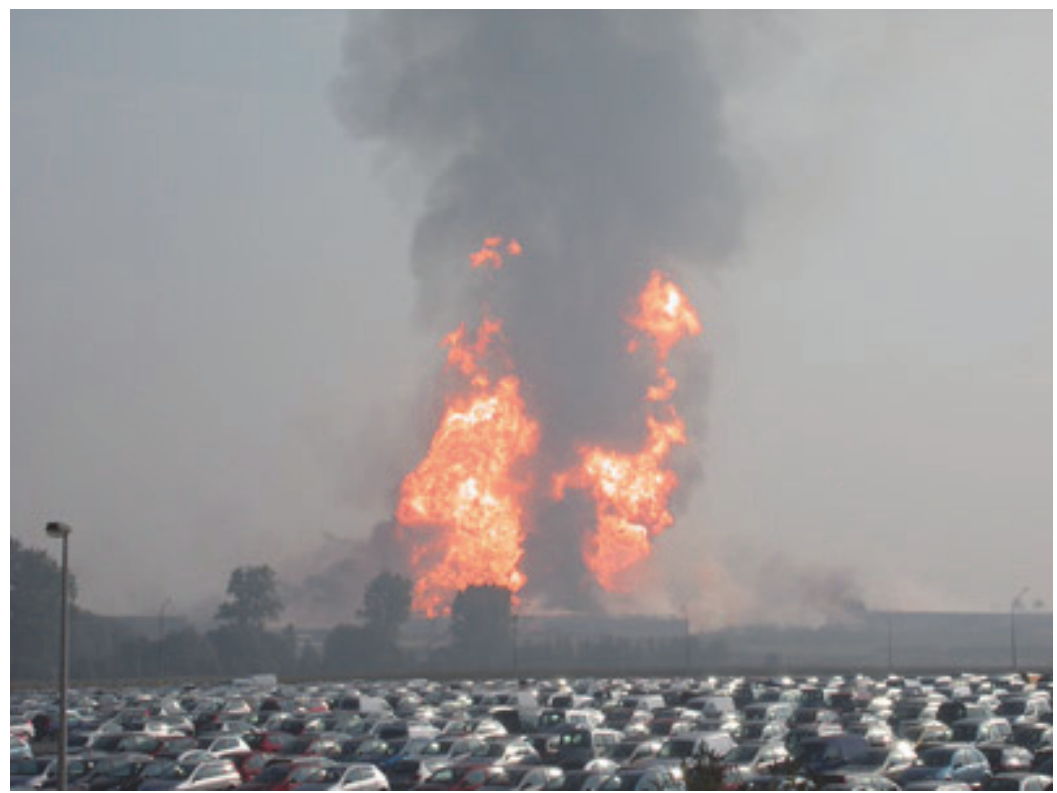

Figure 1. Fluxys gas pipeline explosion at Ghislenghien [1] 


\section{Present State in the Czech Republic}

Nowadays, there are $8000 \mathrm{kms}$ of operational pipeline networks in the Czech Republic, transporting hazardous substances. A substantial part of pipelines is used for the transport of natural gas, namely $3600 \mathrm{kms}$ of pipeline (see Figure 2) operated by the Net4Gas company.

The reliability of operated pipelines is secured by periodical internal inspections of pipelines in the first place. The methods of assessing the material decrease or of the detection of internal faults by the monitoring of magnetic field changes are used. This measurement is performed by means of special inspection piston called "intelligent pig go-devil". The piston is equipped by magnets, magnetic field sensors, and a computer with recording device. After the assessment of measured values, critical points in the pipeline can be detected and proper maintenance plan can be defined [3, 4].

Crude oil is transported to the Czech Republic by Druzba and IKL pipelines (see Figure 3), operated by the MERO CR, joint stock company. The total haul length is 527 $\mathrm{kms}$, out of which $170 \mathrm{kms}$ belong to IKL and $357 \mathrm{kms}$ to Druzba pipeline.
The operational time and increasing pressure of regulatory bodies on the equipment safety bring unprecedented pressure on the operators and make them invest into safety and reliability. Due to above mentioned facts, it is an economic must to keep the pipe system in the best possible state and to monitor collaterally all the parameters that can influence the pipeline integrity and possibly limit or eliminate the risk of accident, whose impacts would be serious in most cases [5, 6].

The IKL pipeline is one of the state-ofthe-art pipelines in the world, with corresponding control and safety systems. The safety system guarantees the safe shuttingdown of the pipeline in case of any technical fault or operator's error. Individual equipment along the pipeline is interconnected with the central control station by communication equipment; the communication is realized by optical cable laid along the pipeline.

The pipeline construction ensures maximum technical level. Apart from this, many controls, measurements, comparisons and inspections are performed that monitor the technical state of pipeline and enable the detection of possible faults and leakages [5].

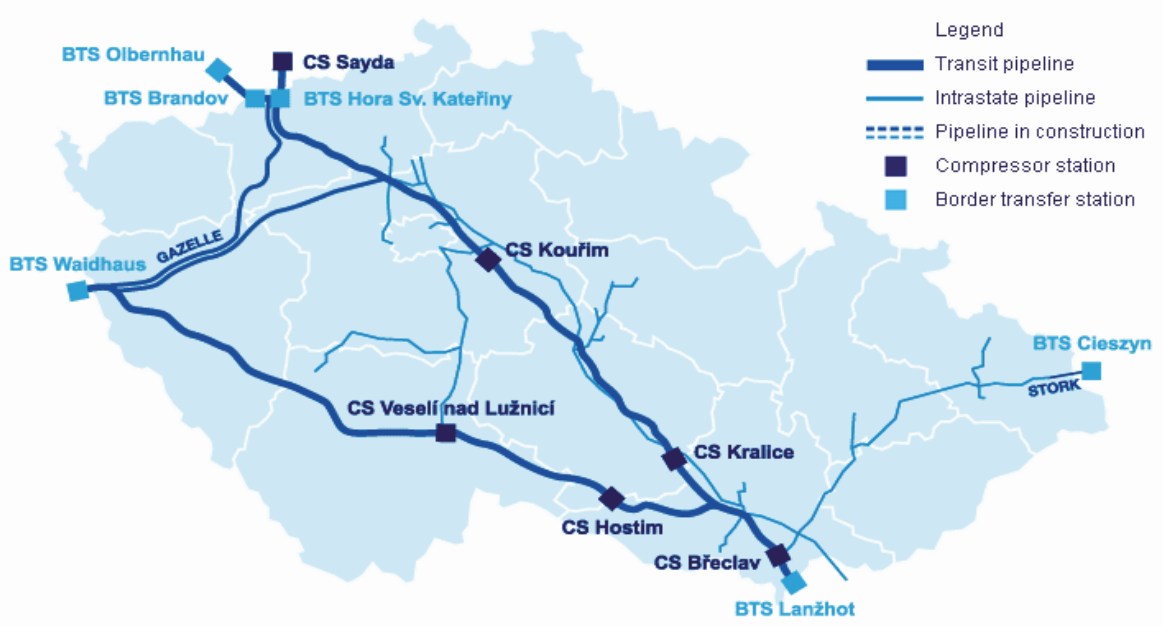

Figure 2. Gas transport system and compressor stations [3] 


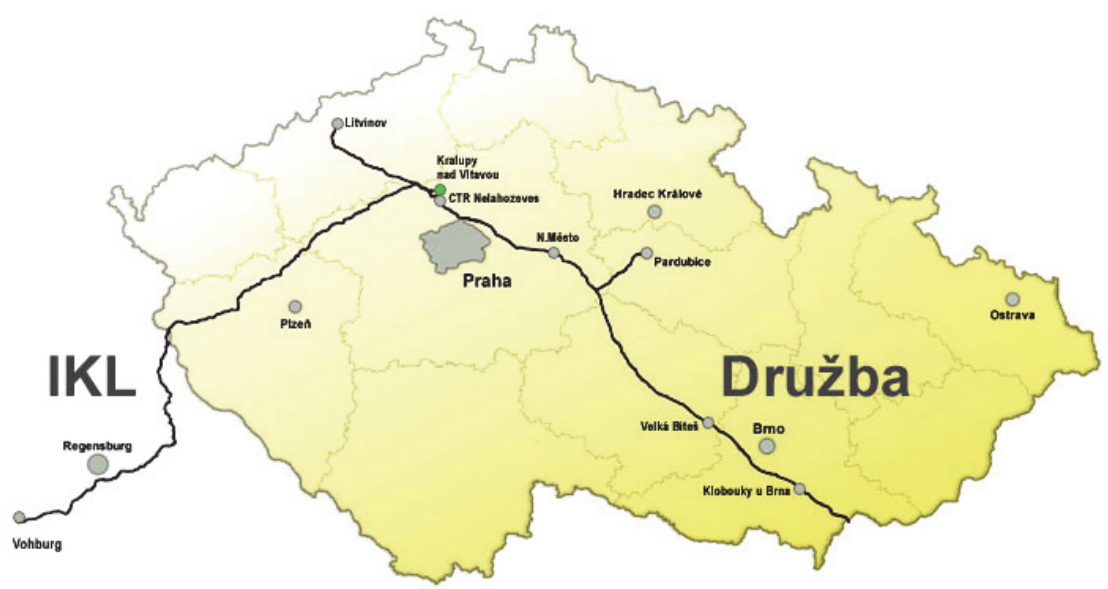

Figure 3. The crude oil pipelines system of the Czech Republic [5]

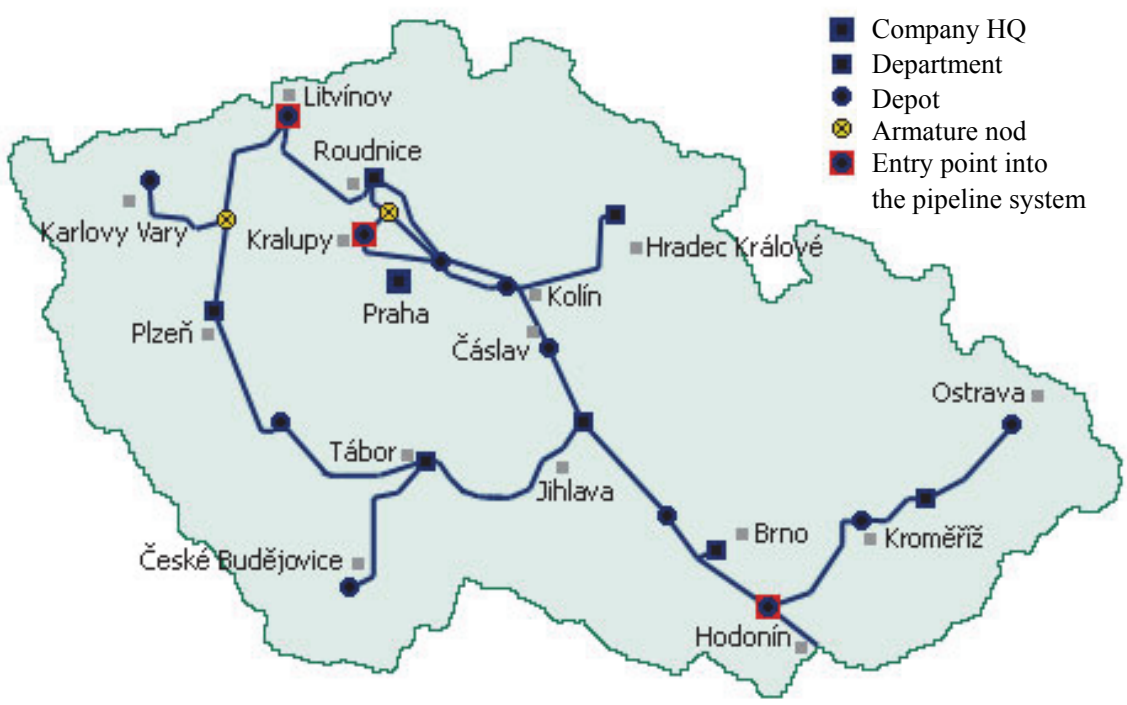

Figure 4. CEPRO company pipeline system [7]

The control system of Druzba pipeline was modernized in such a way that it belongs to the world-class level in safety and reliability. Optical cable was laid along the pipeline enabling safe and fast communication of all the information. The control system enables to control the whole complex system from a single dispatcher station and ensures a safe operation of the pipeline even in cases of technical failure, when the pipeline is automatically and safely shut down.
Exact monitoring of the state of both crude oil pipelines is of utmost importance, as well as the detection of possible crude oil leakage that is signalized by safety leakage system Pipe Deck [4].

More than $1000 \mathrm{~km}$ of pipelines belong to the CEPRO company network (see Figure 4) that transports crude oil products between CEPRO departments and depots, and the refineries in Litvinov and Kralupy nad Vltavou. For safety reasons, the pipeline is 
deposited in the depth of approximately 1.2 meters below the ground level, only in flood areas or in areas with mining or tectonic activities is laid on the surface. The central dispatching station controls the whole pipeline operation, monitors the basic technical parameters of pipeline operation and also the data of safeguard system. Grave peril can be caused by thieves who can cause serious losses not only by theft and equipment damage but also by consequent environmental pollution. For this reason, monitoring systems detecting leakages were installed in places of most frequent thefts. This system can detect the leakages caused by material fatigue $[7,8]$.

\section{Complex Securing of Pipeline Safety}

Pipelines provide for production effectiveness and continuous supplies of raw materials or products but at the same time they constitute a potential line source of the pollution by crude oil substances. Even though many safety precautions are in operation, as mentioned, the occurrence of accidents at certain, and unforeseen, circumstances cannot be avoided.

The safety of equipment with the occurrence of hazardous substances is covered by the Council Directive 2003/105/(ES, so called Amended Seveso II Directive. It is obligatory for EU member states that had to incorporate it into their respective legislations. In the Czech Republic, it is the law No. 29/2006 Sb. on prevention of serious accidents. The level of pipeline safeguarding and regulations in this field can vary in individual UNECE countries. Some pipelines cross borders of two or more countries and at present time no document exists covering the safe operation of pipelines on international level.

UNECE member countries prepared Recommended techniques of pipeline operations in accordance with the Convention on the Transboundary Effects of Industrial Accidents and the Convention on the Protection and Use of Transboundary Watercourses and International Lakes. It provides the set of requirements for the achieving of a basic level of pipelines safeguarding, and contains the rules for pipeline safety, recommendations for pipeline operators and for public administration bodies. It also contains requirements on:

- pipeline construction,

- pipeline management system (PMS),

- emergency planning,

- control,

- regional planning.

Recommended techniques imply unambiguously that pipeline operators have the primal responsibility for safe operation of pipelines during their whole lifespan. The pipelines should be designed and constructed in such a way that enables the prevention of uncontrolled leakage of substance into environment, especially in environmentally sensitive and densely populated areas, and the fast and reliable detection of these leakages. In order to fulfill this requirement the operator should create and introduce the pipeline integrity control system (PMS-PIMS). This system should be designed in such a way that guarantees a high level of human health and environment protection.

The pipelines transporting hazardous substances should be designed, constructed and operated in accordance to valid legal and technical regulations, in order to enable the prevention of accidents or to reduce their impact. The risk analysis and risk assessment should be performed. The regional planning must be taken into account when new pipeline routes and the development of populated areas are proposed [4, 6, 8-11].

\section{Conclusions}

The pipeline network is being enlarged permanently and its expansion is presumable in the future, too. This fact, as well as the growing age of operating pipelines could cause a higher number of accidents, which is not acceptable from the point of view of human health, environment, and property protection. That is why it is necessary to introduce a system that deals not only with the safety of 
operated pipeline alone but with the safety of the whole system - pipeline and its surroundings. The operators should introduce the PMS in the first place. This system can guarantee a high level of human health and environment protection during the construction and operation of pipeline network.

As follows from obtained information, the pipeline operators in the Czech Republic perform many technical and organizational precautions whose aim is to prevent the leakage of transported substance from pipeline into surrounding environment and forego the endangerment of human lives, environment, and property. It is especially about the antirust protection and internal pipe inspections. Some operators achieved such a high level in this field that they introduce PMS in order to increase the safety, for example MERO CR, joint stock company.

\section{References}

1. Proceedings of the Seminar: UNECE Workshop on the Prevention of Accidents of Gas Transmission Pipelines, The Hague, 8-9 March 2006, available at: www.unece.org (дата обращения: 10.05.2014).

2. Proceedings of the Seminar: UNECE Workshop on the Prevention of Water Pollution due to Pipe, Berlin, 8-9 June 2005, available at: www.unece.org (дата обращения: 10.05.2014).

3. Website Net4Gas company, available at: www.net4gas.cz (дата обращения: 10.05.2014)

4. Bryan J.L. Human Behaviour in the Fire the Developmental and Maturity of a Scholarly Study Area // Human Behaviour in Fire Proceedings of the First International Symposium / University of Ulster. - Belfast, 1998. - P. 3-12.

5. Website MERO CR company, available at: www.mero.cz (дата обращения: 12.05.2014)

6. McClintock T. Optimising Exit Choice During Emergecy Evacuations from Large Close Environment. Ph.D. thesis / University of Ulster. Belfast, 2002.

7. Website CEPRO company, available at: www.cepro.cz (дата обращения: 12.05.2014).

8. Morris M., Milos A., Cooper J. Quantification of escalation effects in offshore quantitative risk assessment // Journal of Loss Prevention in the Process industries. - 1991. - № 4(1). - P. 58-64.

9. The proposal of safety regulations for pipelines for UNECE prepared by expert group for water and industrial accidents, available at: www.unece.org (дата обращения: 12.05.2014).

10. Рак Ю.П. Малі друкарські системи: прогнозування, аналіз, синтез. - Киев: Наук. думка, 1999. - 256 с.

11. Meacham B.J., Custer R.L.P. Performance-Based Fire Safety Engineering: An Introduction of Basic Concepts // Journal of Fire Protection Engineering. - 1995. - Vol. 7, № 2. - P. 35-54.

\section{Список литературы}

1. Proceedings of the Seminar: UNECE Workshop on the Prevention of Accidents of Gas Transmission Pipelines, The Hague, 8-9 March 2006, available at: www.unece.org (accessed 10 May 2014).

2. Proceedings of the Seminar: UNECE Workshop on the Prevention of Water Pollution due to Pipe, Berlin, 8-9 June 2005, available at: www.unece.org (accessed 10 May 2014).

3. Website Net4Gas company, available at: www.net4gas.cz (accessed 10 May 2014).

4. Bryan J.L. Human Behaviour in the Fire the Developmental and Maturity of a Scholarly Study Area. Human Behaviour in Fire Proceedings of the First International Symposium. Belfast: University of Ulster, 1998, pp. 3-12.

5. Website MERO CR company, available at: www.mero.cz (accessed 12 May 2014).

6. McClintock T. Optimising Exit Choice During Emergecy Evacuations from Large Close Environment. Ph.D. thesis. Belfast: University of Ulster, 2002

7. Website CEPRO company, available at: www.cepro.cz (accessed 12 May 2014).

8. Morris M., Milos A., Cooper J. Quantification of escalation effects in offshore quantitative risk assessment. Journal of Loss Prevention in the Process industries, 1991, no. 4(1), pp. 58-64.

9. The proposal of safety regulations for pipelines for UNECE prepared by expert group for water and industrial accidents, available at: www.unece.org_(accessed 12 May 2014).

10. Rak Iu.P. Mali drukars'ki sistemi: prognozuvannia, analiz, sintez [Small printing systems: forecast, analysis, synthesis]. Kiev: Naukova dumka, 1999. $256 \mathrm{p}$.

11. Meacham B.J., Custer R.L.P. Performance-Based Fire Safety Engineering: An Introduction of Basic Concepts. Journal of Fire Protection Engineering, 1995, vol. 7, no. 2, pp. 35-54.

\section{About the authors}

Ivana Bartlova (Ostrava, Czech Republic) - Doctor of Technical Sciences, Deputy Head of the Department of Safety Management, Faculty of Safety Engineering, Technical University of Ostrava (VSB - TU Ostrava) (721 00 Ostrava-Vyskovice, Lumirova, 13; e-mail: ivana.bartlova@vsb.cz).

Ales Bernatik (Ostrava, Czech Republic) - Doctor of Technical Sciences, Head of the Department of Safety Management, Faculty of Safety Engineering, Technical University of Ostrava (VSB - TU Ostrava) (721 00 Ostrava-Vyskovice, Lumirova, 13; e-mail: ales.bernatik@vsb.cz).

\section{Об авторах}

Ивана Бартлова (Острава, Чешская Республика) - доктор технических наук, заместитель заведующего кафедрой управления безопасностью, факультет техники безопасности, Технический университет Остравы (721 00, Чешская Республика, г. Острава, Вышковице, ул. Люмирова, 13; е-mail: ivana.bartlova@vsb.cz).

Алес Бернатик (Острава, Чешская Республика) - доктор технических наук, заведующий кафедрой управления безопасностью, факультет техники безопасности, Технический университет Остравы (721 00, Чешская республика, г. Острава, Вышковице, ул. Люмирова, 13; е-таil: ales.bernatik@vsb.cz).

Получено 01.08.2014

Please cite this article in English as:

Bartlova I., Bernatik A. Safety of pipelines in the Czech Republic. Bulletin of PNRPU. Geology. Oil \& Gas Engineering \& Mining, 2014, no. 12, pp. 87-92. DOI: $10.15593 / 2224-9923 / 2014.12 .10$

Просьба ссылаться на эту статью в русскоязычных источниках следующим образом:

Bartlova I., Bernatik A. Safety of pipelines in the Czech Republic // Вестник Пермского национального исследовательского политехнического университета. Геология. Нефтегазовое и горное дело, 2014, no. 12, pp. 87-92. DOI: 10.15593/2224-9923/2014.12.10. 